\title{
Phreodrilidae (Clitellata: Annelida) in north-western Australia with descriptions of two new species
}

\author{
Adrian M. Pinder \\ Science Division, Department of Environment and Conservation, PO Box 51, \\ Wanneroo, Western Australia 6946, Australia
}

\begin{abstract}
Two new species of oligochaete (Clitellata: Annelida: Phreodrilidae) are described from subterranean waters of the Pilbara and Cape Range regions of Western Australia. Phreodrilus limaei sp. nov. from the Pilbara, most closely resembles Phreodrilus peniculus Pinder 2003, also from the Pilbara, but is less widespread. Insulodrilus angela sp. nov. occurs primarily in groundwater, especially within the Ashburton catchment of the Pilbara, but was also collected from two Pilbara springs and from a cave on Cape Range. These, and other undescribed phreodrilids, suggest that north-western Australia, despite being an arid zone, is surprisingly rich in this Gondwanan family.
\end{abstract}

\section{INTRODUCTION}

Thirty two species of Phreodrilidae (in 6 genera) have been described from Australia to date (Pinder 2003b) but at least as many species again await description. The family Phreodrilidae is common in streams and lentic wetlands of temperate southern Australia and particularly diverse in Tasmania and south-western Australia (Pinder and Brinkhurst 1997). The concentration of species in the most temperate parts of Australia fits with the idea that the family is Gondwanan in origin (Martin et al. 2008, Pinder and Brinkhurst 1997). However, while the family is far less widespread in more xeric parts of Australia, new species are increasingly being collected from groundwater and groundwater associated wetlands outside of the temperate zones. Pinder (2003a) described the first endemic aquatic oligochaete, Phreodrilus peniculus, from the arid north-west of Western Australia. Examination of additional material has revealed the presence of numerous other oligochaetes in the region, including some new stygobiotic species. These are part of a regional stygofauna that, with $>350$ species in the Pilbara, is particularly diverse by world standards (Eberhard et al. 2005; Eberhard it al. in press; Humphreys 1999; Humphreys of al. 2005). In this paper, two new phreodrilids are described and the distribution of the family in the north-west is discussed. Undescribed phreodrilids mentioned in the discussion are coded as Phreodrilus WA12, Phreodrilus WA32, Insulodrilus WA35 and phreodrilid WA36 and will be described at a later stage.

This material was collected during several projects: a survey of epigean and hypogean aquatic invertebrates of the Pilbara (Pilbara Biological Survey [PBS], Department of Environment and Conservation: Eberhard of al. (in press) and unpublished data), the Monitoring of River Health Initiative (MRHI) and surveys by Dr W.F. Humphreys of the Western Australian Museum

\section{METHODS}

Groundwater specimens were collected using haul nets as described in Eberhard et al. (in press) and preserved in 100\% ethanol. For the PBS bore sites, oxygen, redox and $\mathrm{pH}$ were measured in-situ using a Yeo-Cal meter and ionic composition and total dissolved solids were analysed from samples collected using a bailer. Surface water specimens were collected with a $250 \mu \mathrm{m}$ mesh sweep net and preserved in $100 \%$ ethanol. Specimens from New Mowbowra Cave were collected by hand from floating root mats. Specimens were stained in Grenacher's borax carmine, dehydrated in isopropanol, cleared in Histoclear and slide mounted in Permount. Drawings were made with the assistance of a drawing tube and measurements were made using Auto-Montage Pro 5.01(A) (The Synoptics Group 2003) with a JVC KY-F1030 video camera calibrated with a stage micrometer.

Type material is deposited with the Western Australian Museum (WAM) and additional material is held by the Department of Environment and Conservation (DEC). Geographic coordinates were measured with a hand-held GPS using datum GDA94, except for New Mowbowra Cave which was either AGD66 or AGD84.

The following abbreviations are used 


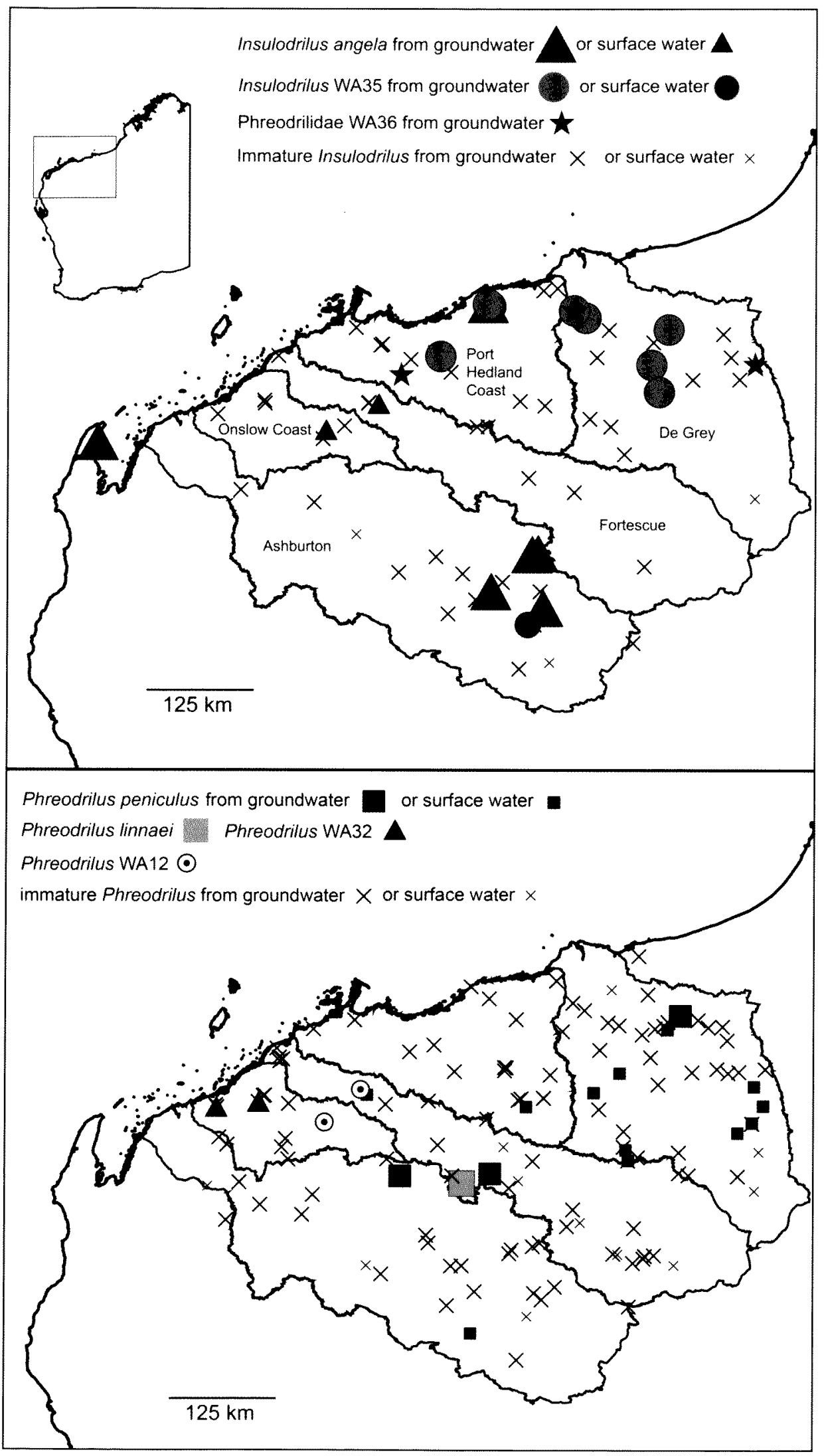

Figure 1 Map showing collection localities for Insulodrilus spp. and an unidentified phreodrilid (top) and Phreodrilus spp. (bottom). Solid lines represent drainage basins as named. Immatures tentatively allocated to Insulodrilus or Phreodrilus on the basis of the form of the ventral chaetae. 
throughout the text: a, atrium; bd, broad portion of spermathecal duct; $c m$, circular muscle on spermathecal duct; ed, ectal portion of spermathecal duct; ff, female funnel; md, median portion of spermathecal duct; $\mathrm{mf}$, male funnel; $\mathrm{p}$, pendant penis; pp, pseudopenis; sa, spermathecal ampulla; sd, spermathecal duct; sv, spermathecal vestibule; $v$, vas deferens. Roman numerals denote segment numbers while numbers in Arabic separated by a slash refer to septa between segments.

\section{SYSTEMATICS}

\section{Family Phreodrilidae Beddard 1891}

\section{Plireodrilus Beddard 1891}

Plireodrilus Beddard 1891: 273.

\section{Type species}

Phreodrilus subterraneus Beddard 1891, by original designation.

\section{Remarks}

Phreodrilus was established for $P$. subterraneus by Beddard (1891) from groundwater in New Zealand but is now also known from another groundwater species in New Zealand, five from Australia (all but one epigean) and one groundwater species from the Arabian Peninsula (Martinez-Ansemil ot al. 2002). The genus is one of the few currently recognised phreodrilid genera with a distinct apomorphy, the coiled protrusible pseudopenes within a muscular sac, which can be everted to form a copulatory organ greater than the body width. Phreodrilus peniculus was described from springs in the Pilbara (Pinder 2003a) and has subsequently been collected from groundwater in the same region (Figure 1).

\section{Plreodrilus linnaei sp. nov.}

Figure 2

\section{Material examined}

Holotype

Australia: Western Australia: Main Roads Department groundwater bore HMBR\#1 on Hamersley Mount Bruce Road about half way between Karijini Drive and Nanutarra-Munjina Road (site PSS043 of PBS), Fortescue River catchment, $22^{\circ} 30^{\prime} 06.3^{\prime \prime} \mathrm{S} 117^{\circ} 57^{\prime} 38.3^{\prime \prime} \mathrm{E}, 21$ November 2002, collected using a haul net, M. Scanlon, J. Cocking (WAM V7430; slide mounted).

\section{Paratypes}

Australia: Western Australia: 2 specimens, collection details as for holotype (WAM V7431, V7432; slide mounted)

\section{Diagnosis}

The combination of a protrusible pseudopenis and a small pendant penis in P. limmaci is otherwise found only in $P$. ponticulus, also from the Pilbara region. However, $P$. peniculus lacks an enlarged mid-portion of the spermathecal duct, has a broad uncoiled pseudopenis and has a larger body (up to $520 \mu \mathrm{m}$ at $X$ ), larger anterior ventral chaetae $(80-120 \mu \mathrm{m})$ and shorter maximum hair length (up to $325 \mu \mathrm{m}$ ). The complex spermathecal ducts of $P$. limnaci, with the widened medial portion, are unique within the family.

\section{Description}

Length unknown, all specimens with posterior missing; width at III 200-210 $\mu \mathrm{m}$ and at XI 310$350 \mathrm{\mu m}$. Prostomium bluntly conical to rounded. Pharynx heavily glandular and muscular in $I$ and II, oesophagus thin walled in III-VIII, enlarging into intestine in VIII. Pharyngeal glands not heavily developed, located ventral and sometimes lateral in IV to $\mathrm{V}$ or $\mathrm{VI}$

Ventral chaetae paired from II, one of each pair bifid, slightly sigmoid, with rudimentary upper tooth and distinct distal nodulus, the other sharply single-pointed, straighter and without nodulus, both $72-85 \mu \mathrm{m}$ in anterior segments (Figure 2D). Ventral chaetae absent on XII, present but unmodified on XIII. Dorsal chaetae dorsolateral from $\mathrm{III}$, each bundle with 1-2 smooth hairs, each surrounded by a pair of support chaetae that do not emerge from the body wall. Hairs $180-524 \mu \mathrm{m}$ long and 1.5 to $2.5 \mu \mathrm{m}$ wide at body wall, tapering to a fine tip, generally increasing in size posteriorly over first few segments.

Clitellum from $1 / 2$ XII to end of XIII, clitellar epithelium 2-3 times width of somatic body wall and consisting of irregular ovoid to rectangular cells. All genitalia and pores paired. Male pores ventro-lateral halfway between $11 / 12$ and $12 / 13$ in line with the ventral chaetae. Female pores and ducts not visible on types. Dorso-lateral slitshaped openings of the spermathecal vestibulae in intersegmental furrow $12 / 13$, in line with dorsal chaetae.

Testes and ovaries antero-ventro-lateral in $X I$ and XII respectively. Developing sperm present from VI to XII. Ventro-lateral cup-shaped sperm-funnels on $11 / 12$, each narrowing to a vas deferens of $8-13 \mu \mathrm{m}$ width which enters pseudopenial sac entally where sac meets atrium. Atrium (Figure 2A-a) consisting of a short blunt (85-108 $\mu \mathrm{m} \times 24-50 \mu \mathrm{m})$ 'tail' on the pseudopenial sac with uneven lining tissue, transforming into a pseudopenis (i.e. with lining tissue dissociated from muscular sac wall) just before joining the vas deferens. Eversible pseudopenis (Figure 

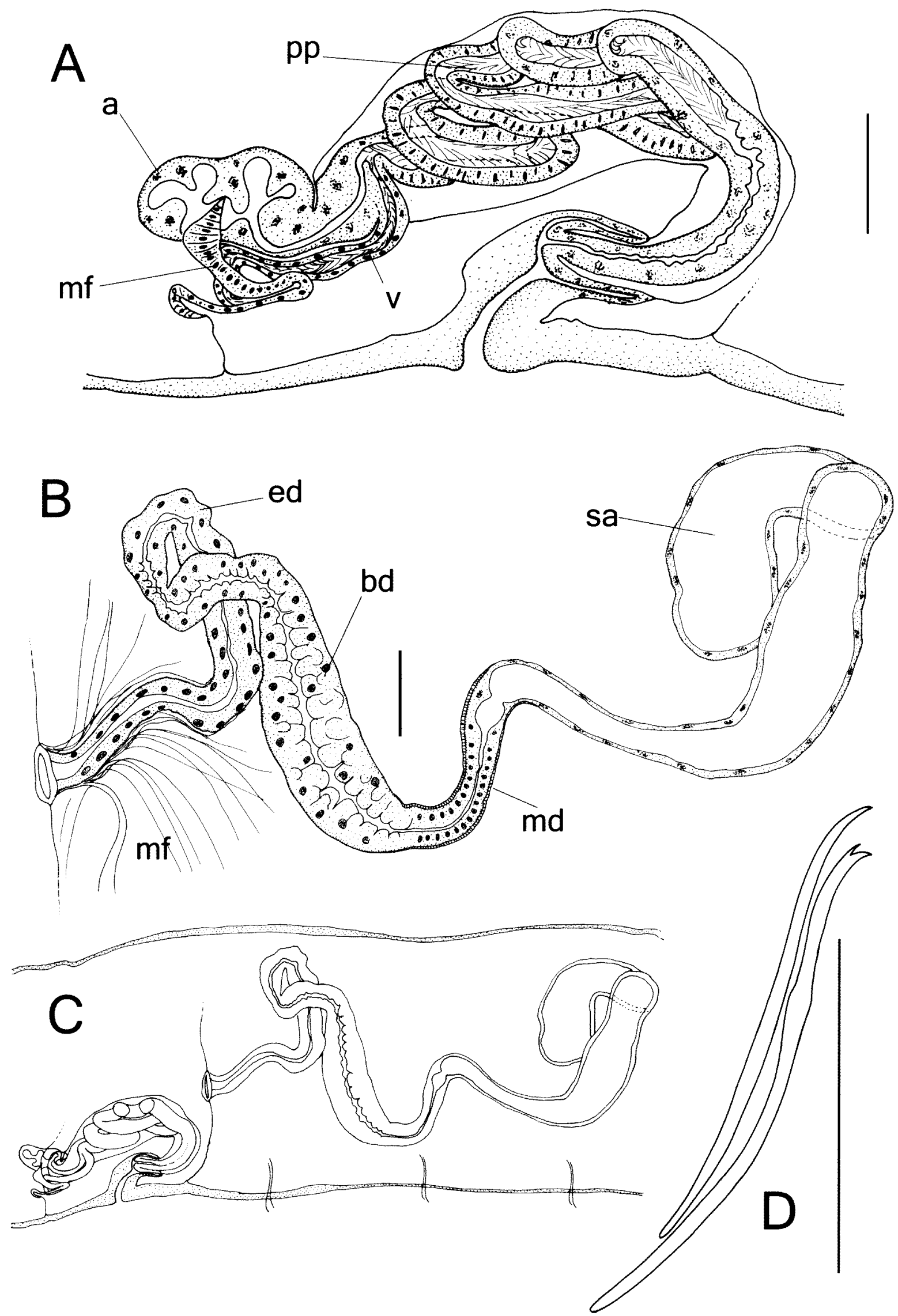

Figure 2 Phreodrilus linnaei sp. nov: A, male genitalia, based mostly on holotype other than ental atrium which is an interpretation from partly obscured and folded atria of the 3 type specimens; $B$, spermathecal duct of holotype; C, genitalia of holotype in situ, D, ventral chaetae of holotype. Scale lines: 50um. 
2A-pp) 15-30 $\mu \mathrm{m}$ wide, loosely coiled within sac and with ciliated lumen about $1 / 3$ width of duct. Sac up to $115 \mu \mathrm{m}$ wide, narrower at either end, ectally forming a duct ( $20-40 \mu \mathrm{m}$ wide) containing the (now unciliated) pseudopenis, the whole duct protruding into the penial sac to form a short (15-45 $\mu \mathrm{m}$ long $\times 25-26 \mu \mathrm{m}$ wide) double-walled pendant penis occupying $\%$, to $\%$ of the penis sac.

Spermathecal ampullae (Figure 2B-sa) elongate, with walls mostly consisting of lining tissue (4-6 $\mu \mathrm{m})$, muscle not visible, and loosely folded in $X I V$ and $X V$, filled with sperm in loose masses in mated individuals. Ampulla narrowing ectally to form a short duct (Figure $2 \mathrm{~B}-\mathrm{md}$ ) of varying width $(19-33 \mu \mathrm{m})$ and length $(130-160 \mu \mathrm{m})$, with a narrow lumen, broader lining tissue and a circular muscle layer. The latter opens into a broader glandular section of duct (180-270 x 40-85 $\mu \mathrm{m}$ ) with large lining cells and a very thin muscle layer (Figure 2B-bd), which then narrows to form a loose duct (width 25-35 $\mu \mathrm{m}$ ) (Figure 2B-ed). This duct covered by longitudinal muscles in its ectal portion which branch off as long thin fibres (Figure $2 \mathrm{~B}-\mathrm{mf}$ ) that join the body wall at various points.

\section{Remarks}

The term protrusible pseudopenis was used by Brinkhurst (1965) to describe the portion of the male genital ducts that is a slightly to strongly coiled and ciliated tube within a thin-walled sac of Plreodrilus species. This tube is everted from the male pore during copulation. This has been thought of as a modification of the ectal part of the atrium, which is normally a glandular organ consisting of an inner laver of glandular lining cells around a lumen and an outer layer of muscle cells. Such a modification from atrium to protrusible penis could have arisen by separation of the lining tissue from the muscle tissue, leaving a tube (protrusible penis) within a tube (sac) (Brinkhurst 1965). However, the lumen of the standard atrium is never ciliated whereas vasa deferentia (which normally feed into the atria) are ciliated. This suggests that the mostly ciliated protrusible penes of Phreodrilus may in fact be highly modified vasa deferentia (P. Martin, Institut Royal des Sciences Naturelles de Belgique, pers. comm.) rather than atria. Cilia are absent from the most ectal part of the pseudopenis, but modified vasa deferentia of some of the species lack cilia ectally (Gustarsson and Erséus 1999). In most other aquatic oligochaetes the penes are conical to elongate structures located within an invagination of the body wall at the external opening of the male duct and often referred to as pendant penes. While the coiled structures present in Phreatrilus are clearly not homologous to pendant penes, they nonetheless perform a penis-like function of sperm transfer and the term protrusible pseudopenis remains apt.

The small pendant penis present in all specimens of $P$. peniculus and $P$. limmaci does not appear to be the same as the partially everted pseudopenis that is occasionally seen in other Phredrilus specimens, e.g. as illustrated for Phrodrilus stocki (Martinez-Ansemil it al. 2002).

Water sampled from the type locality was neutral freshwater dominated by sodium and bicarbonate (Table 1).

\section{Etymology}

Named in honour of Carolus Linnaeus (17071778 ) on the 250 th anniversary of the publication of the $10^{\text {th }}$ edition of Systema Naturat and the $300^{\text {th }}$ anniversary of his birth.

\section{Insulodrilus Brinkhurst 1991}

Insulodrilus Brinkhurst 1991: 2040.

\section{Type species}

Phreodrilus lacustris Benham 1903, by original designation.

\section{Remarks}

Insulodrilus was established following a phylogenetic analysis by Brinkhurst (1991) for species with pendant penes and with female pores not located within the (generally small) spermathecal vestibulae. However, Brinkhurst noted that this grouping was probably paraphyletic and only an interim 'conservative measure'. Species of the otherwise similar Astacopsidrilus (Goddard, 1909) are distinguished from lisulodrilus by the presence of female pores that are located within greatly enlarged spermathecal vestibulae. However, these are characters of degree and some Insulodrilus have well developed spermathecal ampulla and some Astacopsidrilus have female pores spermathecal pores only just within or co-incident with the openings of the restibulae. Future analyses of the family Phreodrilidae will most likely result in these genera being synony mised or (perhaps more likely) split into multiple smaller genera. The new species below has moderately well developed vestibulae with separate female pores. The genus occurs in New Zealand, South America, Africa and Australia. Eight species have previously been described from Australia, with most known only from Tasmania.

\section{Insulodrilus angela sp. nov.}

Figure 3 


\section{Material examined}

Holotype

Australia: Western Australia: bore WAWB51, West Angela mine site, approximately $100 \mathrm{~km}$ NW of Newman (PBS site PSS167), 23009'11.6"S, $118^{\circ} 44^{\prime} 51.3^{\prime \prime} \mathrm{E}, 14$ October 2004, H. Barron, J. Cocking (WAM V7433, slide mounted (left coverslip).

\section{Paratypes}

Australia: Western Australia:, 1 specimen on same slide (right coverslip) as holotype, collection details as for holotype (WAM V7434); 2 specimens, Nyeetbury Spring (site PSW016 of PBS), $21^{\circ} 51^{\prime 2} 9^{\prime \prime}$ S, 116 30'57"E, 15 May 2005, A. Pinder, J. McRae (WAM V7435, slide mounted); 1 specimen, Nyeetbury Spring (site ONS03 of MRHI), 21 $51^{\prime} 36^{\prime \prime} \mathrm{S}$, 116 30'42"E, 11 May 1996, W. Kay, M. Smith (WAM V7436; slide mounted); 1 specimen, Bore WB32,

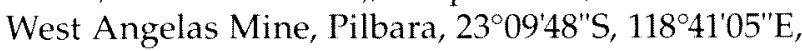
6 October 1998, S. Eberhard (WAM V7437; slide mounted); 1 specimen, Bore YR15/73 (site PSS132 of PBS), Yule River borefield, Pilbara, 20 32'19.2"S, $118^{\circ} 13^{\prime}$ 02.1'E, 12 October 2004, J. Cocking, $\mathrm{H}$. Barron (WAM V7438; slide mounted); 1 specimen, Limestone Bore (site PSS394 of PBS), Pilbara, $22^{\circ} 43^{\prime} 32.6^{\prime \prime} \mathrm{S}, 118^{\circ} 48^{\prime} 02.4^{\prime \prime} \mathrm{E}, 20$ August $2004, \mathrm{M}$. Scanlon, H. Barron (WAM V7439; slide mounted); 1 specimen, floating root mat in New Mowbowra Cave, a non-anchialine cave on the coastal plain on the eastern side of Cape Range, 21 $59^{\prime} 34^{\prime \prime} S$, $114^{\circ} 07^{\prime} 19^{\prime \prime} \mathrm{E}, 26$ June 1993, W. Humphreys (WAM V7440; slide mounted).

\section{Other material examined}

Australia: Western Australia: 2 specimens, Millstream Delta (PBS site PSW011, a warm spring), Millstream National Park, Pilbara, $21^{\circ} 34^{\prime} 58^{\prime \prime} \mathrm{S}, 117^{\circ} 04^{\prime} 08^{\prime \prime} \mathrm{E}, 24$ August 2003, A. Pinder, J. McRae (DEC slide 68); 1 sperimen, Limestone Bore (site PSS394 of PBS), Pilbara, $22^{\circ} 43^{\prime} 32.6^{\prime \prime S}$, $118^{\circ} 48^{\prime} 02.4^{\prime \prime} \mathrm{E}, 20$ August 2004, M. Scanlon, H. Barron (DEC slide 188); 1 specimen, Bore TCS002 (site PSS388 of PBS), 23'33'06.8'S, 118 $15^{\circ} 16.7^{\prime \prime} \mathrm{E}, 9$ May 2005, M. Scanlon, H. Barron (DEC slide 202).

\section{Diagnosis}

Insulodrilus angela differs from other described Insulodrilus primarily in the size and form of the spermathecal vestibule and the un-modified somatic chaetae. Other species lacking modified somatic chaetae are I. lacustris s. str. (see Remarks), I. martensi Martin and Giani 1995 (from Africa, with alveolate penes, thickened septa in the genital region and short stiff hairs), I. genitalisetifera Martin and Brinkhurst 1994 (also from Africa, with genital chaetae in XI and XIII and an alveolate penis) and Insulodrilus litoralis Michaelsen 1903 (from the subantarctic Campbell Island, with long slender atria, smaller spermathecal vestibulae and ventral chaetae as described for lacustris).

\section{Description}

Body of slide-mounted specimens $170-290 \mu \mathrm{m}$ wide at III, 225-375 $\mu \mathrm{m}$ wide at $X$, most specimens missing posterior but one complete specimen $6.05 \mathrm{~mm}$. Prostomium rounded and conical, pharynx in III, strongly muscular posteriorly with thick muscle connections to dorso-lateral body wall of II-V. Pharyngeal glands on lower half of anterior and posterior sides of septa $4 / 5$ to $6 / 7$ or $7 / 8$ and laterally on oesophagus in $\mathrm{V}$ to VII. Oesophagus widening into gut in VIII-X.

Ventral chaetae $(55-80 \mu \mathrm{m})$ from $\mathrm{II}$, all paired and bifid with small but distinct upper teeth (Figure 3A). Ventral chaetae of XIII modified: one long (85-105 $\mu \mathrm{m})$ and hollow tipped, protruding either end of the large spermathecal chaetal gland, the other short and not protruding. Ventral chaetae of XII absent. Dorsal chaetae from III, 1 to 2 smooth hairs, each surrounded by a pair of support chaetae, mostly 110-480 $\mu \mathrm{m}$ long (rarely shorter), tapering evenly to a fine tip.

Genitalia paired. Male pores ventro-lateral in posterior third of XII in line with the ventral chaetae. Testes antero-ventral in XI, ovaries antero-ventral in XII. Female ducts penetrate $12 / 13$ to exit at pores immediately anterior of the opening of the spermathecal vestibule anteroventral on XIII in line with the ventral chaetae (Figure 3B-ff). Thin clitellum from $1 / 2$ XII to end of XIII, not developed ventrally on XII.

Narrow $(7.5$ to $9.5 \mu \mathrm{m})$ ciliated vas deferens (Figure 3B-v) joins elongate (35-44 $\mu \mathrm{m}$ wide, 270-540 $\mu \mathrm{m}$ long) unciliated atrium (Figure 3B-a) as the latter narrows just before entering penis (join not visible on holotype but seen on some paratypes). Atrium with lumen of variable width, probably reflecting reproductive stage. Slender pendant penis occupying most of the penis sac. Spermathecal vestibule vase-shaped ectally (Figure 3B-sv) with longitudinal muscle layer and numerous muscle filaments extending from the vestibule to the dorso-lateral body wall and septa. The vestibule dilated at its dorsal extremity and surrounded by circular muscle tissue (Figure 3B$\mathrm{cm})$, bending posteriorly to join a spermathecal duct (Figure 3B-sd) above the spermathecal chaetal gland. Ducts joining voluminous ampullae in XIV, which extends into at least XV. Sperm in loose oval bundles in ampulla.

\section{Remarks}

These specimens were at first identified as Insulodrilus lacustris s. $l$, the suffix indicating that 


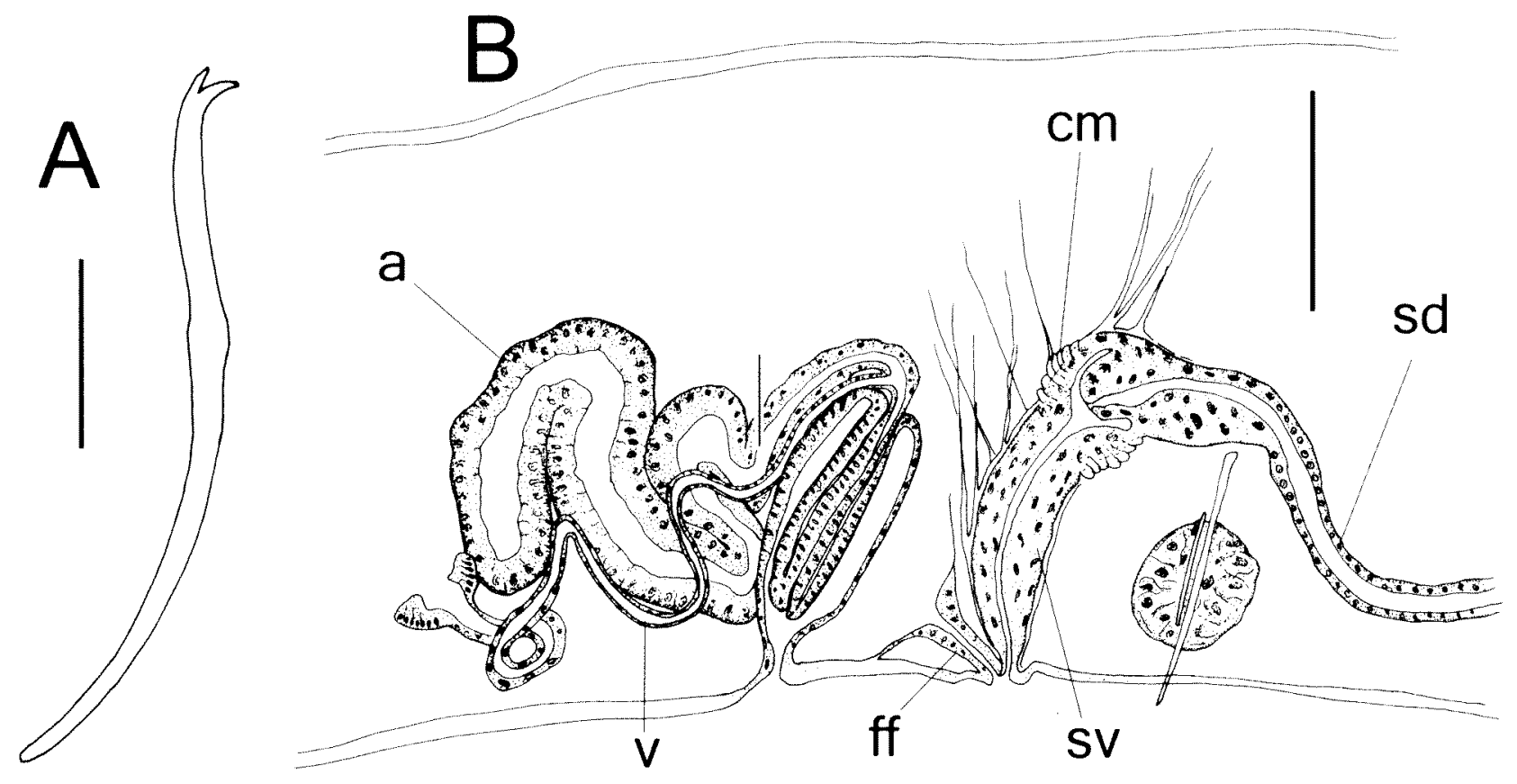

Figure 3 Insulodrilus angela sp. nov: A, ventral chaeta; B, genitalia, excluding the spermathecal ampulla. Scale lines: A, $20 \mu \mathrm{m} ; \mathrm{B}, 100 \mu \mathrm{m}$.

this name has been given to what now appears to be a complex of similar species in Australia.

Despite indications to the contrary by Pinder and Brinkhurst (1997), the Australian specimens differ from I. lacustris s. str. (as described by Benham, 1903 from New Zealand specimens) in a number of respects. In contrast to all Australian forms, I. lacustris has narrow and simple spermathecal vestibulae, hardly differentiated from the duct apart from the presence of longitudinal muscles in the former and circular muscles in the latter. They also have dorsal chaetae that project only $1 / 4$ to $1 / 3$ the body height and scarcely half the segment length (whereas most Australian forms have the hair chaetae as long as or longer than the body height) and have anterior ventral chaetae with one chaeta of a pair clearly bifid and the other almost simple (just a rudimentary hint of a tooth) whereas in Australian specimens both chaetae in all ventral pairs are always distinctly bifid.

The several forms of lacustris-like Insulodrilus in Australia differ in the extent of development of the spermathecal vestibule and ducts, length of the atrium, body size, chaetal size and a number of other features. The states of these characters seem be consistent and distinct within geographic regions and sufficient to recognise a number of species, including 1 . angela and a nother undescribed Pilbara species Insulodrilus WA35. Almost all phreodrilids have limited geographic distributions (Pinder and Brinkhurst, 1997; Pinder 2001) and the recognition that the Australian "lacustris" are in fact multiple endemic species fits this pattern.

All specimens were collected in circum-neutral fresh to slightly brackish $(<2.4 \mathrm{~g} / \mathrm{L})$ water with variable ionic composition, including dominance by sodium with bicarbonate, or magnesium with chloride, sulphate or bicarbonate.

\section{Etymology}

This species is named after the type locality, a bore near West Angela Hill.

\section{DISCUSSION}

The global distribution of the Phreodrilidae indicates a Gondwanan origin (Martin of al. 2008. Pinder and Brinkhurst 1997) and, to date, the majority of species have been found in places that seem to offer refugia from past or present aridity: alpine areas, high southern latitudes, groundwater or deep lakes. Astacopsidrilus atwant Pinder 2003, which occurs in ephemeral seepages on granite outcrops, is an apparent exception, though nothing is known of where it survives when the seepages are dry. The occurrence of seven (mostly still undescribed) phreodrilids in the arid Pilbara is further evidence that the family occurs more widely within Australia than previously thought. Their occurrence mostly 
in groundwater associated habitats fits with a general pattern of taxa of presumed Gondwanan origin occurring preferentially in refugial/ relictual habitats when they occur in arid zones [e.g., some water mites (Harvey 1998) and phreatoicid isopods (Knott and Halse 1999)]. Three of the Pilbara phreodrilids have been collected only in groundwater, and another two have been collected only in groundwater plus springs and spring fed pools. Only the undescribed Phreodrilus WA12 has not been found in groundwater to date but its only known locality is a spring-fed creek. Phreodrilus peniculus is particularly widespread in the region's surface waters, including deep gorge pools, springs, spring fed pools and river pools without a flowing spring but which are probably permanent as a result of hyporheic inflow. There is a single record of an immature specimen from a seasonal turbid creek pool with no obvious groundwater influence.

Eberhard et al. (in press) discuss the difficulty of determining the ranges of groundwater species, particularly in relation to sampling effort. Their analyses indicated that $70 \%$ of stygal species may have ranges $<10,000 \mathrm{~km}^{2}$ (which Harvey (2002) proposed as an upper threshold for short range endemism). This has impact assessment implications for the many resource developments in the Pilbara that are dewatering aquifers. Three phreodrilids may have small ranges (Figure 1): P. limnaei is presently known only from its groundwater type locality, the undescribed Phreodrilus WA12 is known only from two springs (one on the Robe River and one on the adjacent lower Fortescue River) and Phreodrilus WA32 is known from two groundwater bores in close proximity on the coastal plain near the Cane River. Phreodrilid WA36 is more widespread but also infrequently collected and known only from groundwater. Insulodrilus angela and the undescribed Insulodrilus WA35 are widespread, common and found in groundwater and (less frequently) surface waters (Figure 1). Insulodrilus angela occurs in at least four drainage basins in the Pilbara plus a cave on Cape Range. Insulodrilus WA35 occurs mostly in groundwater of two basins (DeGrey and Port Hedland Coast) whose floodwaters occasionally merge in their lower reaches, but one record in a groundwater-fed pool is a geographic outlier separated from other records by the eastern Hamersley Ranges. Phreodrilus peniculus appears to be the most common and widespread species (Figure 1). Immature specimens with chaetae resembling Insulodrilus (both chaetae of a pair bifid) or Phreodrilus (one simple and one bifid chaeta in each bundle) have been found across the Pilbara. These may just be immatures of the already common species but their wide distribution 
indicates that the full picture of phreodrilid distributions in the Pilbara is yet to be revealed.

Springs fed by discharging groundwater or hyporheic flow are present throughout the Pilbara region and the occurrence of the same phreodrilid species in both these springs and in groundwater suggests that the springs are a portal for movement between surface and groundwater. Epigean movement within catchments, and between catchments when coastal floodwaters merge, would also be enhanced by the regular and severe floods resulting from cyclonic rains. Changes to flow paths and isolation of ancient river tributaries by rising sea levels have perhaps also contributed to the occurrence of these species across present catchment divides. For example, the Fortescue River formerly flowed to the coast via what is now the lower Robe River but is now entirely separate. Similarly, the Ashburton River, which now flows to the coast near Onslow, is believed to have been in close proximity to Cape Range between the Middle Miocene and Late Pleistocene (Wyrwoll et al. 1993), bringing it much closer to the record of $I$. angela from the Cape. Knott (1993) advanced the latter concept as an explanation for the presence of the limnostygobiont shrimp Stygiocaris stylifera and two subterranean fish species on the Cape, all three of which co-occurred with 1 . angela in New Mowbowra Cave (W.F. Humphreys, Western Australian Museum, pers. comm.).

\section{ACKNOWLEDGEMENTS}

The Pilbara Biological Survey was funded by the Department of Environment and Conservation Western Australia, the Australian Government through the Natural Heritage Trust, and Straits Resources. The Monitoring of River Health Initiative was funded by the Commonwealth Government through the National Heritage Trust and Land \& Water Australia and by the State Government through Department of Environment and Conservation and the Water and Rivers Commission. William Humphreys of the Western Australian Museum kindly provided specimens and data collected with financial assistance from the National Estates Program, the Heritage Council of Western Australia, the Water Authority of Western Australia and the Western Australian Museum. Susan Jones helped prepare the map. Mike Scanlon assisted with slide mounting and identifying some of the specimens.

\section{REFERENCES}

Beddard, FE. (1891). Anatomical description of two new genera of aquatic Oligochaeta. Transactions of the Royal Society of Edinbureh 36: 273-303.

Benham, W.B. (1903). On some new species of aquatic
Oligochaeta from New Zealand. Procedtings of the Zoological Society of London 2: 202-232

Brinkhurst, R.O. (1965). A taxonomic revision of the Phreodrilidae (Oligochaeta). fommal of Zoology 147 363-386.

Brinkhurst, R.O. (1991). A phylogenetic analysis of the Phreodrilidae (Annelida, Oligochaeta), with a description of a new species. Conadian foumml of Zoology 69: 2031-2040.

Eberhard, S.M., Halse S.A. and Humphreys, W.F. (2005) Stygofauna in the Pilbara region, north-west Western Australia: a review. Foumal of the Royal Socity of Westernt Australia 88: 167-176.

Eberhard, S.M., Halse, S.A., Williams, M., Scanlon, M.D., Cocking, J.S and Barron, H.J. (in press) Exploring the relationship between sampling efficiency and short range endemism for groundwater fauna in the Pilbara region, Western Australia. Freshwater Bology.

Goddard, E.J. (1909). Contribution to a further knowledge of Australasian Oligochaeta. Part I. Description of two species of a new genus of Phreodrilidae. Procedings of the Limnean Society of New South Wales 33: 768-793.

Gustavsson, L.M. and Erséus, C. (1999). Development of the genital ducts and spermathecae in the rhyacodrilines Rhyacodrilus coccinels and Monopylephorus rubronious (Oligochaeta, Tubificidae) Joumal of Morphology 242: 141-156.

Harvey, M.S. (1998). Unusual new water mites (Acari: Hydracarina) from Australia, Part 1. Records of the Western Australian Museum 19: 91-106.

Harvey, M.S. (2002) Short-range endemism among the Australian fauna: some examples from nonmarine environments. mertebrate Systematics 16: 555-570.

Humphreys, W.F. (1994). The subtermenen fauma of the Cape Range coastal plain, northuestern Australia. Report to the Australian Heritage Commission and the Western Australian Heritage Committee. 202 pp. Western Australian Museum, Perth

Humphreys, W.F. (1999). Relict stygofaunas living in sea salt, karst and calcrete habitats in arid northwestern Australia contain many ancient lineages. II: W. Ponder and D. Lunney (eds). The other 99\%. The conseration and biodiversity of incertebrates: 219-227. Royal Zoological Society of New South Wales, Mosman.

Humphreys, W.F., Watts C.H.S. and Bradbury J.H. (2005). Emerging knowledge of diversity, distribution and origins of some Australian stygofauna. In: J. Gilbert (ed.). Procedings of an lnternational Symposinm on World Subternatean Biodicherity: 57-60. Villeurbanne, France, 8-10 December 2004. University of Lyon, France.

Knott, B. (1993). Stygofauna from Cape Range peninsula, Western Australia: Tethyan relicts. Records of the Western Australian Musium Supplement 45: 109-127.

Knott, B. and Halse, S.A. (1999). Pillaraphratotots n. gen., n.sp. (Isopoda: Phreatoicided: Amphisopodidae) from the Pilbara region of Western Austratia. Records of the Austrolin Musetum 51: 33-12

Martin, P. and Brinkhurst, R.O. (1994). A new species of lasulodrilus (Oligochaeta, Phreodrilidae) from Lake Tanganyika (East Africa) with notes on the oligochaete fauna of the lake. Archio for Hydro-biologie 130: $249-256$. 
Martin, P. and Giani, N. (1995). Insulodrilus martensi, a new species of Phreodrilidae (Oligochaeta) from Lake Tanganyika (East Africa). Annals of Limnology 31: 3-8.

Martin, P., Martinez-Ansemil, E., Pinder, A.M., Timm, T., Wetzel, M.J. (2008). Global diversity of oligochaetous clittelates ("Oligochaeta"; Clitellata) in freshwater. Hydrobiologia 595: 117-127.

Martinez-Ansemil, E. Giani, N. and Sambugar, B. (2002). Oligochaetes from underground waters of Oman with descriptions of two new species of Phreodrilidae (Oligochaeta): Antarctodrilus arabicus n. sp. and Phreodrilus stocki n. sp. Contributions to Zoology 71: 147-158.

Michaelsen, W. (1903). Die Oligochaten der Deutschen Tiefsee-Expedition, nebst Erorterung der Terricolenfauna oceanischer Inseln, insbesondere der Inseln des subantarktischen Meeres. Wissenschaftliche Ergebnisse der Deutschen Tiefsee-Expedition auf den Damfer "Valdivia", 1898-1899 3: 131-168.

Pinder, A.M. and Brinkhurst, R.O. (1997). A review of the Phreodrilidae (Annelida: Oligochaeta: Tubificida) of Australia. Invertebrate Taxonomy 11: 443-523.
Pinder, A.M. 2001. Notes on the diversity and distribution of Australian Naididae and Phreodrilidae (Oligochaeta: Annelida). Hydrobiologia 463: 49-64.

Pinder, A.M. 2003a. New species and records of Phreodrilidae (Annelida: Clitellata) from Western Australia. Records of the Western Australian Museum 21: 307-313.

Pinder, A.M. (2003b). Clitellata; Oligochaeta; Tubificata and Lumbriculata. Australian Faunal Directory. Australian Biological Resources Study, Canberra. Viewed 17 June 2008. http://www.environment. gov. au/ biodiversity/abrs/online-resources/fauna/afd/ index.html

The Synoptics Group (2003). Auto-Montage Pro User Manual. The Synoptics Group: Cambridge.

Wyrwoll, K-H., Kendrick, G.W. and Long, J.A. (1993). The geomorphological evolution of the Cape Range Exmouth Gulf region. Records of the Western Australian Museum, Supplement 45: 1-23.

Manuscript received 19 February 2008; accepted 7 July 2008. 